\title{
Androgénreceptor mediálta folyamatok metasztatikus kasztrációrezisztens prosztatadaganatban
}

\author{
Küronya Zsófia dr. - Bíró Krisztina dr., \\ Gyergyay Fruzsina dr. - Géczi Lajos dr.
}

Országos Onkológiai Intézet, „C” Belgyógyászati-Onkológiai és Klinikai Farmakológiai Osztály, Budapest

\begin{abstract}
A metasztatikus kasztrációrezisztens prosztatadaganat kezelésében az elmúlt hat évben öt új hatóanyag került törzskönyvezésre. E szerek szekvenciális alkalmazásával ebben a továbbra is gyógyíthatatlan betegségben jelentős túlélést lehet elérni, jó életminőség mellett. Az elmúlt évtized kutatásainak köszönhetően, egyértelmúvé vált, hogy a betegség progressziójának középpontjában az androgénreceptor mediálta folyamatok állnak. Az androgénreceptort érintő hormonális mechanizmusok a betegség késői stádiumáig funkcióképesek maradhatnak. Ezeknek a mechanizmusoknak még pontosabb megismerése vezetett a nómenklatúra megváltoztatásához, az új endokrin terápiák bevezetéséhez. Az új terápiák során jelentkező primer, illetve szekunder rezisztencia hátterében álló androgénreceptor-mutációk identifikálása, remodellezése újabb, még hatékonyabb androgénreceptor-gátló kezelésekhez nyithat utat. A szerzők ismertetik az androgénreceptorszignál-tengely patofiziológiáját, receptoriális szinten bemutatják a már engedélyezett gyógyszereket, valamint felhívják a figyelmet a legígéretesebbnek túnő fejlesztésekre is. Orv. Hetil., 2017, 158(2), 42-49.
\end{abstract}

Kulcsszavak: kasztrációrezisztens prosztatadaganat, androgénreceptor, abirateron, enzalutamid, ARV7, galeteron

\section{Androgen receptor-mediated processes in castrate-resistant metastatic prostate cancer}

In the past six years, five new drugs have been approved by the FDA for the treatment of metastatic castrate-resistant prostate cancer. While the disease itself still remains incurable, the sequential use of these drugs can significantly prolong survival while maintaining good quality of life. Research from the past decade made it clear that androgen receptor-mediated processes play a central part in the progression of the disease. Hormonal mechanisms related to androgen-receptors can remain active until late stages of the disease. A deeper understanding of these mechanisms has led to the introduction of new endocrine therapies, which resulted in a change of the nomenclature. The identification and remodelling of androgen receptor mutations that are responsible for primary and secondary resistance developing during the new therapies can pave the way to new and more efficient androgen receptor inhibitor treatments. The aim of the review is to present the pathophysiology of the androgen receptor signaling axis at the receptor level, to review FDA-approved drugs and to draw attention to the most promising developments in the treatment of this disease.

Keywords: castrate-resistant prostate cancer, androgen receptor, abiraterone, enzalutamide, ARV7, galeterone

Küronya, Zs., Bíró, K., Gyergyay, F., Géczi, L. [Androgen receptor-mediated processes in castrate-resistant metastatic prostate cancer]. Orv. Hetil., 2017, 158(2), 42-49.

(Beérkezett: 2016. augusztus 14.; elfogadva: 2016. november 5.)

A metasztatikus prosztatadaganat kezelése kórélettanilag két stádiumra osztható: hormonérzékeny és kasztrációrezisztens szakaszra. A hormonérzékeny szakasz kezelésében a mai napig Huggins 1966-ban Nobel-díjjal jutal- mazott 1941-es megfigyelésének van szerepe, miszerint amennyiben a herék eltávolításra kerülnek, a prosztatadaganat mérete csökken [1]. Az androgéndepriváció (ablatio), azaz a tesztoszteronhiány előidézése jelenleg a 
Enzalutamid docetaxel után

2012. 08. 31.

Sipuleucel-T

2010. 04. 29.

Cabazitaxe

2010. 06. 17
Abirateron docetaxel után

2011. 04. 28.
Abirateron docetaxel előtt

2012. 10. 12

\section{Radium223}

2013. 05. 15.
Enzalutamid

docetaxel elótt

2014. 10. 09. metasztatikus prosztatacarcinoma standard terápiájának tekintendő. A betegek többségénél az androgénablatióval PSA-szint-csökkenés, a betegséggel összefüggő tünetek enyhülése észlelhető, valamint képalkotó vizsgálatokkal igazolható az áttétek méretének csökkenése. Az elmúlt két év átütő eredményének számít, hogy az ebben a szakaszban alkalmazott úgynevezett korai kemoterápia lényegesen javítja a teljes túlélést $[2,3]$.

$\mathrm{Az}$ androgéndeprivációra a betegek $80 \%$-a reagál, de pár éven belül a betegek felében kasztrációrezisztens állapot alakul ki.

2011-tôl került bevezetésre a ma már nemzetközileg elfogadott nómenklatúra. Az új endokrin terápiák bevezetésével világossá vált, hogy habár a betegség progrediál, a daganat továbbra is hormonszenzitív maradhat, így a hormon independens/refrakter fogalmat ma már nem használjuk [4].

Kasztrációrezisztens prosztatacarcinomáról (CRPC) az Európai Urológiai Társaság (EUA) definíciója alapján akkor beszélünk, ha androgéndeprivációs terápia mellett vagy biokémiai, vagy radiológiai progresszió következik be, annak ellenére, hogy a szérumtesztoszteron-érték a kasztrációs szint alatt van (1,7 nmol/l alatt) [5].

- Biokémiai progresszió: Három egymást követő, legalább egy hét különbséggel mért PSA-szint emelkedése, amelyből két érték a nadírhoz képest 50\%-os emelkedést mutat és a PSA>2 $\mathrm{ng} / \mathrm{ml}$.

- Radiológiai progresszió: Csontlaesio progrediál vagy minimum két új laesio jelent meg a csontszkenen vagy RECIST (Response Evaluation Criteria In Solid Tumors) szerint visceralis metasztázis vagy $2 \mathrm{~cm}$-nél nagyobb nyirokcsomó progrediál.

Az elmúlt hat évben az amerikai Food and Drug Administration (FDA) öt új kezelést engedélyezett a metasztatikus CRPC kezelésében:

2010-ben a sipuleucel-T-immunterápiát (Európában nem elérhető) és a cabazitaxel-kemoterápiát, 2011-ben az abirateront, amely a nómenklatúra megváltoztatását tette szükségessé, 2012-ben az enzalutamidot, majd 2013-ban a radium-223 izotópkezelést (1. ábra).

Az elmúlt időszakban számtalan klinikai vizsgálat fut az engedélyezett szerek kombinációival, illetve új szerek tesztelésével. Fontos hangsúlyozni, hogy a fókuszban to- vábbra is az androgénreceptor mediálta folyamatok még pontosabb megismerése és ennek megfelelően ezen folyamatok lehetséges gátlása áll.

Összefoglalónkban ismertetjük az androgénreceptor(AR-) szignál-tengely patofiziológiáját, receptoriális szinten bemutatjuk a már engedélyezett gyógyszereket, valamint felhívjuk a figyelmet a legígéretesebbnek tűnő fejlesztésekre is (1. táblázat).

1. táblázat |AR-re ható törzskönyvezett készítmények

\begin{tabular}{|c|c|c|}
\hline Hatóanyag & Gyógyszernév & $\begin{array}{l}\text { FDA-enge- } \\
\text { délyezés } \\
\text { éve }\end{array}$ \\
\hline
\end{tabular}

I. Preveceptoriális stratégiák

LH RH-agonisták

$\begin{array}{ll}\text { Leuprorelin } & \begin{array}{l}\text { Eligard, Lucrin, } \\ \text { Leuprorelin }\end{array}\end{array}$

$\begin{array}{ll}\text { Goserelin } & 1989\end{array}$

Triptorelin Decapeptyl, Diphereline 2000

\begin{tabular}{lll} 
Buserelin & Suprefact & 2004 \\
\hline LH RH-antagonisták & & \\
Degarelix & Firmagon & 2008
\end{tabular}

CYP450 enzim gátlók

\begin{tabular}{lll} 
Abirateron & Zytiga & 2011 \\
\hline II. Receptoriális stratégiák & \\
\hline AR-antagonisták &
\end{tabular}

Első generációs

Flutamid $\quad$ Flutam, Fluprost, 1989

Flutasin, Fugerel

Bicalutamid Bicalutamid, Bicalutatam, 1995

Bicatlon, Bicusan,

Bilutamid, Binabic

Calumid, Capro,

Casodex, Sanotamid

$\begin{array}{lll}\text { Nilutamid } & \text { Anandron } & 1996\end{array}$

\begin{tabular}{l} 
Második generációs \\
Enzalutamid Xtandi $\quad 2012$ \\
\hline III. Posztreceptoriális stratégiák \\
\hline Jelenleg nincs törzskönyvezett készítmény
\end{tabular}




\section{$\mathrm{Az}$ androgénreceptorszignál-tengely}

A prosztatasejtek növekedése, múködése, osztódása fiziológiásan androgénfüggő. A tesztoszteron - bár nem tumorkeltő hatású - nélkülözhetetlen a daganatos sejtek növekedéséhez és fennmaradásához. A testisek termelik a tesztoszteron 90-95\%-át, a többi a mellékvese által termelt androgénekből (androszténdion, dehidroepiandroszténdion, dehidroepiandroszténdiol) képződik az izom-, a zsír- és az idegszövetekben. A tesztoszteron kiválasztását a hypothalamus-hypophysis-gonadalis tengely szabályozza. A hypothalamus luteinizálóhormonfelszabadító hormonja (LH RH) stimulálja az agyalapi mirigyet, hogy az luteinizáló hormont (LH) és tűszőérést serkentő hormont (FSH) szabadítson fel. A luteinizáló hormon serkenti a herék Leydig-sejtjeit a tesztoszteron kiválasztására. A prosztatasejtben a tesztoszteront az 5- $\alpha$-reduktáz enzim alakítja át 5- $\alpha$-dihidrotesztoszteronná (DHT); a DHT a tesztoszteronnál mintegy 10-szer erősebb androgénstimuláns hatással rendelkezik és csak ez képes bekötődni az androgénreceptorhoz (AR). A ligandaktivált szteroid típusú hormonreceptor transzkripciós faktorként három különálló doménnel rendelkezik, DNS-kötő, C-terminális ligandkötő, valamint az $\mathrm{N}$-terminális transzaktivációs doménnel $[6,7]$.

Androgén hiányában az AR a citoplazmában helyezkedik el, hősokk- (heat-shock) fehérjéhez és co-chaperon molekulákhoz (Hsp70, Hsp40 és Hsp90) kapcsolódva, amelyek megakadályozzák az AR lebomlását, valamint a sejtmagba való belépését. Amikor az AR ligandkötő doménjéhez bekötődik a DHT, konformációs változás jön létre a receptorban, amely dimerizációhoz, foszforilációhoz, nukleáris transzlokációhoz, DNS-kötődéshez, valamint koaktivátorok jelenlétében az androgén által aktivált gének transzkripciójához vezet $[8,9]$.

Eközben a keringő tesztoszteron perifériásan aromatizálódik, és ösztrogénné alakul át, amely a keringő androgénekkel együtt negatív visszacsatolással szabályozza a hypothalamus LH-elválasztását.

A CRPC kialakulásában központi szerepe van az AR mediálta folyamatoknak. A rezisztencia kialakulásához vezető, AR-rel összefüggő legfontosabb patomechanizmusok a következők [10]:

- AR-overexpresszió (génamplifikáció és/vagy fehérjeoverexpresszió), amelynek következtében a receptor alacsonyabb szintű ligandra is érzékennyé válik és aktiválódik.

- Génmutáció és megváltozott ligandspecificitás, amelynek következtében a nem androgén szteroidokra és magára az antiandrogénre is reagál a receptor, ez magyarázhatja, hogy antiandrogén-megvonásra átmeneti PSA-csökkenés érhető el. Alternatív splicing mechanizmus, amely olyan AR-t eredményezhet, amely ligandkötődés nélkül is aktiválódik.

- Ligandfüggetlen receptoraktiváció, különböző szignáltranszdukciós utak aktiválásán keresztül, amely által kis androgénkoncentráció mellett vagy annak hiányában is aktiválódik az androgénreceptor.

- Össejtszelekciók, amelyek nem expresszálnak AR-t.

- Intratumoralisan a tesztoszteront szintetizáló enzimek fokozott múködése.

A fentieken kívül jelentősége van a mellékveséből vagy a zsírszövetből származó extraprosztatikus androgénszintézisnek is.

A daganat kialakulásával és progressziójával párhuzamosan a prosztatát körülvevő stromalis sejtek megváltoznak. A progresszióban meghatározó szerepe van az epithelium-stroma közötti interakciónak, amely során a megváltozott mikrokörnyezetben számos parakrin jelátviteli útvonal aktiválódik, ami a daganat fennmaradását és növekedését biztosítja.

Mindezen mechanizmusok közül ma a meghatározó az androgénreceptor aktiválásához kötött mechanizmus, ezért ez a mechanizmus kulcsszerepet játszik a daganat progresszióját gátló kezelés megtervezésekor.

A kezeléseket az AR-hez való viszonyuk alapján tárgyaljuk.

\section{Prereceptoriális szintü kezelési stratégiák}

A prereceptoriális kezelések célja a tesztoszteron terápiás, kasztrációs szintre való csökkentése $(<50 \mathrm{ng} / \mathrm{dl}$ $[1,7 \mathrm{nmol} / \mathrm{l}])$, illetve a tesztoszteron-bioszintézés gátlása.

\section{Szérumtesztoszteron-szint kasztrációs szintre csökkentése}

Az androgéndepriváció elérhető a herékben termelődő tesztoszteron szuppressziójával sebészeti vagy gyógyszeres kasztráció révén.

\section{Sebészeti kasztráció}

Bilateralis orchidectomia még mindig az androgéndeprivációs terápia aranystandardjának tekinthető, ehhez hasonlítjuk a többi hormonális kezelést. A mütét a tesztoszteronszint jelentős csökkenését eredményezi, amely hypogonadalis állapothoz vezet, bár a tesztoszteron nagyon alacsony szintje (az úgynevezett „kasztrációs szint”) megmarad. Érthető okokból a betegek többsége a beavatkozást visszautasítja.

\section{Kémiai kasztráció}

\section{Ösztrogénterápia: dietil-stilböszterol (DES)}

Az ösztrogén több szinten fejti ki hatását, részben negatív feed-backen keresztül az LH RH-t szorítja vissza, ami az LH- és tesztoszterontermelés csökkenéséhez vezet, másrészt inaktiválja az androgént és direkt módon gátolja a Leydig-sejteket. A szintetikus ösztrogének gátolják a 
mellékvese androgéntermelés-prekurzorát, a dihidroepiandroszteront (DHEA), valamint in vitro adatok alapján a prosztataepitheliumra is toxikusak [11].

A Veterans' Administration Cooperative Urological Research Group klinikai vizsgálata 1960-ban igazolta, hogy $5 \mathrm{mg} /$ nap DEA a kasztrációval azonos daganatellenes hatást fejt ki, de jelentôs cardiovascularis morbiditás és mortalitás mellett. Annak ellenére, hogy erőfeszítések történtek a cardiovascularis komplikációk csökkentésére, az ösztrogén használata kiszorult a mindennapos alkalmazásból.

\section{LH RH receptoragonisták}

Fiziológiásan az LH RH tíz aminosavból álló polipeptid, amit a hypothalamus 90 percenként $10-15$ perces időtartamban pulzálva választ ki. Az LH RH aminosavszekvencia felfedezése új fejezetet nyitott a metasztatikus prosztatadaganat kezelésében, tartós hatású, szuperaktív analógok kerültek klinikai forgalomba egy-, két-, három-, hathavi és éves depot formájában. A kezelés kezdetén öt-hét napig a szuperaktív hosszú hatású gyógyszer hatására a hypophysis elülső lebenye által termelt FSH és LH szérumszintje, és ennek következtében a szérumbeli tesztoszteronszint is nő, legmagasabb értéke a hetedik napon mérhető. A magas LH RH analóg szérumszint hatására a hypophysis elülső lebenyében lévố sejtek úgy reagálnak, hogy a sejtmembránban lévő LH RH receptorainak számát fokozatosan és jelentősen csökkentik. Down reguláció alakul ki, ennek következtében a szérum LH FSH szintje csökken és a harmadiknegyedik hétre kialakul a kémiai kasztráció, azaz a szérumtesztoszteron a kasztrációs szintre csökken. Az első héten, a szérum növekvő tesztoszteronszintjének megfelelően, a klinikai tünetek átmenetileg rosszabbodhatnak (flare up), amely jelenséget antiandrogéneknek az első két hétben történő egyidejű adásával ki lehet és ki is kell védeni. Egyesek szerint az LH RH kezelés megkezdése előtt már egy héttel érdemes elkezdeni az antiandrogének adását.

Magyarországon négy LH RH, más néven Gn RH analóg hatóanyag van forgalomban: triptorelin (Decapeptyl, Diphereline), buserelin (Suprefact), goserelin (Zoladex), leuprorelin (Lucrin, Eligard, Leuprorelin).

Tíz randomizált klinikai vizsgálat metaanalízise alapján az LH RH analógok által elérhetô túlélés, klinikai kimenetel (tesztoszteron- és PSA-szint) és a progresszióig eltelt idő ekvivalens a sebészi kasztrációval [12].

Bár direkt összehasonlító vizsgálat nem történt, a rendelkezésre álló adatok alapján a forgalomban lévő LH RH analógok teljes túlélésre gyakorolt hatásában nincs különbség, azonban 2015 novemberétől Magyarországon az egészségbiztosító csak a Leuprorelin Sandozt és az Eligardot finanszírozza.

\section{LH RH antagonista}

Az LH RH analógok okozta flare up kivédésére és a kasztrációig eltelt idő csökkentésére az 1990-es években kezdték el kifejleszteni az LH RH-receptorantagonistákat.

Az első készítmény, amelyet az FDA 2003-ban engedélyezett, az abarelix volt, azonban allergiás mellékhatások miatt 2005-ben visszavonták. A degarelix használatát 2008-ban engedélyezte az FDA. Már a kezdő adag beadása után azonnal csökken a plazma tesztoszteronszintje. A beadás után három nappal a betegek $96 \%$-ának, egy hónap múlva pedig a 100\%-ának a plazmatesztoszteron-szintje a gyógyszeres kasztrációs szintre csökken. Mellékhatása csak a lokális (injekció) reakciókra korlátozódik, hátránya, hogy nem áll rendelkezésre depot formuláció [13].

Az LH RH agonisták és antagonisták alkalmazása a betegség mindkét szakaszában szükséges, mivel retrospektív vizsgálatok alapján ezzel megnövelhető a betegek túlélése [14].

\section{Tesztoszteron-bioszintézés gátlása}

\section{CYP450 enzim gátlók}

A tesztoszteron túnyomó része ( $>90 \%$ ) a herékben szintetizálódik, a fennmaradó rész pedig a mellékvesében és az izom-, a zsír- és az idegszövetekben termelődik. A mellékvesében termelődő androgén szabályozásában kulcsszerepet játszik a hypothalamus által termelt kortikotropinfelszabadító hormon (CRH), amely a hypophysis elülső lebenyében az adrenokortikotrop hormon (ACTH) felszabadulását idézi elő. Az ACTH aztán aktiválja a tesztoszteron és a dehidroepiandroszteron (DHEA) szintézisét a mellékvesében. A prosztatában a tesztoszteron nagyrészt a mellékveséboól származó DHEA-ból vagy más szteroid-elővegyületekből szintetizálódik. Az LH RH-analógok nincsenek hatással a CRHés ACTH-termelésre és ezért csak a herékben termelődő tesztoszteronszintézist képesek visszaszorítani. Ez egy fontos klinikai problémára hívja fel a figyelmet. A tesztoszteron vagy a DHT már kis mennyiségben is képes aktiválni az AR-eket. A mellékveséboól származó és az intratumorálisan termelődő androgének a kasztrációrezisztencia kialakulásában döntő szerepet játszanak.

A tesztoszteron bioszintézisében központi szerepet játszó enzim minden szervrendszerben a citokróm P450-C17 (CYP17), ezért a CYPl7 célzott gátlása, mind a gonadalis, mind a mellékvesében, mind az intratumorálisan termelődő androgént képes visszaszorítani és csökkentheti az általános tesztoszteronszintet még az LH RH agonistákkal-antagonistákkal történő kezelés után is [15].

\section{Ketoconazol}

Az elsóként alkalmazott citokróm P450-gátló kezelés prosztatadaganatban a ketoconazol volt, amely antimi- 
kotikum. A ketoconazol hatékonynak bizonyult a tesztoszteron és a DHEA csökkentésében, de pan-CYP450inhibitorként csökkentette a mellékvese-kortikoszteroidok termelődését is. Következésképpen a kezelés folyamatos hidrokortizonszubsztitúciót igényel és gyakoriak a gyógyszer-interakciók. Mellékhatásai miatt használata háttérbe szorult. Mindazonáltal a ketoconazol nemkívánatos (off-target) hatásai nyomán indult el a kutatás a specifikusan CYP17-et gátló kezelések irányába [16].

\section{Abirateron (Zytiga)}

A specifikus CYP17-gátlókat célzó kutatás az 1990-es években az abirateron felfedezéséhez vezetett. Az abirateron (Zytiga) a pregnenol szteroidhomon-elővegyület származéka, amely szelektíven és irreverzibilisen gátolja a CYP17 hidroláz- és liázaktivitását. A mellékhatásprofil a CYP17 gátlása révén kialakuló alacsony kortizolszint okozta ACTH-emelkedéssel járó mineralokortikoid-túlsúllyal magyarázható, amely kis dózisú prednisolon adásával kivédhető.

A COU-AA-301 vizsgálat eredményei alapján az FDA 2011-ben engedélyezte használatát, olyan kasztrációrezisztens metasztatikus prosztatarákban szenvedő betegek kezelésére, akiknek betegsége docetaxelkezelés alatt vagy a kemoterápiás kezelést követően progrediál [17].

Ebben az indikációban Magyarországon is elérhető a készítmény egyedi méltányossági kérelem alapján. 2012 decemberében a COU-AA-302-es vizsgálat alapján az FDA engedélyezte az abirateron szedését olyan metasztatikus kasztrációrezisztens prosztatatumorban szenvedő betegeknél is, akik sikertelen androgéndeprivációs kezelést követően tünetmentesek vagy csak enyhe tüneteket mutatnak, és akiknél a klinikai állapot alapján kemoterápiás kezelés még nem indokolt. Ebben az indikációban Magyarországon még nem elérhető [18].

Fontos hangsúlyozni, hogy az abirateron volt az első olyan endokrin terápia, amely megváltoztatta azt a dogmát, hogy a prosztatadaganat hormonrezisztens, ezáltal új távlatokat nyitott a CRPC kezelésében.

\section{Orteronel}

A kutatások egy része még specifikusabb CYP17-gátlófejlesztésekre fókuszál, amelynek egyik lehetséges módja olyan hatóanyagok alkalmazása, amelyek kizárólagosan a CYP17 liázfunkcióját gátolják. Ez a stratégia elméletileg képes lenne specifikusan az androgénszintézis gátlására, miközben a CYP17 hidrolázaktivitása változatlan marad, ezáltal a mineralokortikoidszintézis sem változik. Ezen új gyógyszerek egyike az orteronel (TAK-700), egy imidazolszármazék, amely ötször hatékonyabban gátolja a CYP17 liázaktivitását, mint a hidroxilázaktivitását, és kevésbé fejt ki nemkívánatos hatásokat [19].

Ígéretes fázis I-II-es vizsgálatokat követően a fázis III-as vizsgálatban az orteronel + prednisolon kombinációs kezelés növelte ugyan a progressziómentes túlélést, de az elsődleges végpont, a teljes túlélés tekintetében nem bizonyult hatékonynak a prednisolonkarral szem- ben [20]. Kemonaiv betegekkel futó fázis III-as vizsgálat eredményei még nem állnak rendelkezésre.

\section{Receptoriális szintü kezelési stratégiák}

A prereceptoriális kezelések legnagyobb hátránya az, hogy ezen hatóanyagok többsége nem gátolja hatékonyan az AR-ektől függő jelpályák funkcionális végpontjait. A receptorszintű stratégiák az AR-ek expressziójának és aktivitásának csökkentését vagy gátlását tüzik ki célul. Ez utóbbi olyan gyógyszerek alkalmazásával valósulhat meg, amelyek képesek kompetitíven kötődni az AR ligandkötő doménjéhez (LBD), így megakadályozva az aktív AR-DHT komplex kialakulását. Az antiandrogéneknek első és második generációs csoportját különböztetjük meg.

\section{Az $A R$ aktivitásának csökkentése}

\section{Első generációs antiandrogének}

$\mathrm{Az}$ antiandrogének két csoportra oszthatók: szteroidok és nonszteroidok. A szteroidok cyproteront és megestrolt tartalmaznak, a nonszteroid hatóanyagok közé tartozik a flutamid, bicalutamid és nilutamid. Ez utóbbi három vegyület alkotja az első generációs antiandrogének csoportját.

A hatóanyagok az androgénreceptorhoz való affinitásukban és a mellékhatásprofiljukban különböznek.

Teljes androgénblokádról (TAB) akkor beszélünk, ha az LH RH-analógot, illetve a sebészeti kasztrációt antiandrogénekkel egészítjük ki a hatékonyság növelése érdekében. Huszonhét klinikai vizsgálat metaanalízise (LH RH-analóg mellett antiandrogént randomizáltak placebóval szemben) igazolta, hogy a TAB csak kismértékben, 2-5\%-kal javítja az ötéves túlélést (Prostate Cancer Trialists' Collaborative Group 2000). Ezzel szemben a kombinációs kezelésben a mellékhatások száma nőtt, a kezelési költségek is lényegesen emelkedtek. Ennek alapján a TAB-kezelés első vonalban nem javasolt, kivéve a kezelés első két hetében a flare kivédésére [21].

Ma az új endokrin terápiák (abirateron, enzalutamid) birtokában az első generációs, „vintage” antiandrogének klinikai alkalmazása fokozatosan háttérbe szorul, hiszen a TAB-kezelés a progressziót késleltetheti, de a teljes túlélésre nincs lényeges hatással [22].

\section{Második generációs antiandrogének \\ Enzalutamid (Xtandi)}

$\mathrm{Az}$ enzalutamid egy új androgénreceptor-antagonista, egy második generációs antiandrogén, amelynek a bicalutamidhoz képest négy-nyolcszoros az AR-hez való affinitása. Az enzalutamid abban különbözik az első generációs AR-től, hogy képes blokkolni az androgénreceptor-szignalizációt azáltal, hogy gátolja a ligand-receptor komplex nukleáris transzlokációját.

Az AFFIRM fázis III-as vizsgálat eredményei alapján az FDA 2012-ben engedélyezte a kezelést olyan meta- 
sztatikus CRPC-s betegeknél, akiknél kemoterápia után progresszió volt tapasztalható [23]. Ebben az indikációban Magyarországon is elérhető a készítmény egyedi méltányossági kérelem alapján.

A PREVAIL fázis III-as vizsgálat alapján az FDA a készítményt az abirateronnal megegyező indikációban 2014 szeptemberében engedélyezte kemonaiv betegeknél is [24]. Hazánkban kemonaiv betegek kezelésére támogatással nem rendelhető.

\section{$A R N-509$}

Az ARN-509 az enzalutamiddal egy szerkezeti csoportba tartozó vegyület. Az ARN-509 aktivitása is hasonló az enzalutamidhoz, mivel az ARN-509 specifikusan gátolja az AR-ek nukleáris lokalizációját és DNS-hez kapcsolódását. Jelenleg fázis III-as vizsgálatban vizsgálják hatékonyságát, nem metasztatikus kasztrációrezisztens betegeknél [25].

\section{$O D M-201$}

Bár az ARN-509 még fázis III-as vizsgálat alatt áll, az esetlegesen kialakuló rezisztencia egyik okát a vizsgálat során sikeresen igazolták: az ARN-509, az enzalutamidhoz hasonlóan, AR-F876L-mutánsok megjelenésével agonistaként viselkedhet. Az antagonista-agonista jelenség kiküszöbölésére került kifejlesztésre az ODM-201. A molekula egy olyan carboxamid, amely hatékonyabban gátolja az AR-t, mint az enzalutamid vagy az ARN-509. Jelenleg, az ARN-509-hez hasonlóan, fázis III-as vizsgálatban tesztelik, nem metasztatikus kasztrációrezisztens betegeknél [26].

\section{AR-expresszió gátlása}

Klinikai tapasztalatok alapján mind az abirateron-, mind az enzalutamidkezelés mellett előbb-utóbb rezisztencia kialakulásával kell számolni. A rezisztencia hátterében olyan AR-splice-variánsok mutathatók ki, amelyekről hiányzik a C-terminális, ligandkötő domén, azaz az ARligand (DHT) bekötődése nélkül is konstitucionálisan aktív. Ez idáig több mint húsz hasítási variánst írtak le, amelyek közül a leggyakoribb és legjelentősebb az ARV7 izoforma. Az AR-V7 variáns N-terminális, ligandtól független transzkripciót aktiváló doménje folyamatosan aktív állapotban tartja az androgén jelátviteli útvonalat [27].

Antonarakis és mtsai prosztatatumoros betegek véréből izolált keringő tumorsejtekben (CTC) vizsgálták az AR-V7-expresszió meglétét abirateron- vagy enzalutamidkezelés megkezdése előtt, a kezelés folyamán és a progresszió bekövetkezésekor. A vizsgálatban 62 beteg vett részt. A kezelés megkezdése előtt AR-V7-negatív betegeknél a PSA-válasz aránya 61\%-os, míg az AR-V7pozitív betegeknél $0 \%$-os volt (primer rezisztencia). A medián progressziómentes túlélés 6,4 vs. 2,1 hónapnak, az átlagos túlélés több mint 16,0 vs. 9,9 hónapnak bizonyult az AR-V7-negatív betegek javára. Azon betegek eredményei, akik a kezelés során vagy a progresszió időpontjában váltak AR-V7-pozitívvá (szekunder rezisztencia), a primeren rezisztens és a tartósan AR-V7-negatív betegek PSA-válaszadási aránya és progressziómentes túlélési ideje között helyezkedtek el [28].

Ezen eredmények alapján felmerül, hogy az AR-V7expresszió az abirateron- és az enzalutamidkezelés hatékonyságának prediktív biomarkere lehet, azonban az AR-V7-expresszió vizsgálómódszerei, mint reverz transzkripciós polimeráz láncreakció (RT-PCR), immunhisztokémiai módszerek, illetve keringő tumorsejtekben való meghatározás még nem standardizáltak és nem validáltak. Bár az eddigi eredmények biztatóak, az AR-V7expresszió prediktív jelentőségét prospektív klinikai vizsgálatokban is igazolni kell [29].

\section{Galeteron}

AR-V7-expresszió esetén is hatékony kezelési stratégia lehet a galeteron, amely az egyik legígéretesebbnek tünő fejlesztés CRPC-ben, hiszen három hatásmechanizmust ötvöz. Egyrészről az abirateronhoz hasonlóan gátolja a CYP17-et, másrészról az enzalutamidhoz hasonlóan megakadályozza az AR-ek transzkripciós aktivitását, valamint elősegíti mind az AR, mind pedig az AR-V7 és más hasítási variánsok proteoszomális lebomlását [30].

Az ARMOR3-SV fázis III-as vizsgálatban olyan betegek körében tesztelték a galeteron hatékonyságát, akiknél kimutatható volt az AR-V7 expressziója, kontrollkarként az enzalutamidot alkalmazták. 2016. július 26-án azonban a vizsgálatot leállították, mert előzetes elemzések alapján az elsődleges végpontot, a radiológiai progressziómentes túlélést a galeteron nem javítja. A fázis IIes ARMOR2 vizsgálat, amelyben enzalutamidkezelés alatt progrediáló betegeknél tesztelik a galeteront, továbbra is aktív, az eredményekre még várni kell.

\section{Niclosamid}

A niclosamid féregűzőként törzskönyvezett szer, amelyrôl kiderült, hogy elősegíti az AR-V7 lebomlását. Preklinikai tanulmányok alapján a niclosamid hatékonyan csökkenti a tumor növekedését enzalutamidrezisztens sejtvonalból származó humán xenograftokban. Ezek az eredmények azt mutatják, hogy a niclosamid azáltal, hogy elősegíti az AR-V7 lebomlását, hatékony lehet azon betegek kezelésében, akiknél az enzalutamidterápia után progresszió tapasztalható vagy akár alkalmazásával az enzalutamidrezisztencia is megelőzhető [31].

A galeteron és a niclosamid az első tagjai lehetnek annak az új hatóanyagcsoportnak, amelyet szelektív androgénreceptor-csökkentőknek (selective androgen-receptor down-regulators - SARDs) vagy androgénreceptor-lebontást fokozónak (androgen receptor degradation enhancers - ARD enhancers) neveznek [32]. 


\section{Posztreceptorszintü kezelési stratégiák}

A posztreceptoriális kezelési stratégiák azon fehérjéket veszik célba, amelyek az AR-ek stabilitásában és az ARektől függő génaktivációban vesznek részt. A lehetséges célpontok sokfélesége, az AR-ek transzkripciós tevékenységének összetett mechanizmusai és az AR-gént szabályozó molekuláris pályák bonyolultsága miatt a posztreceptoriális hatóanyagok fejlesztése számos megoldandó problémát vet fel és jelenleg a legnagyobb kihívást jelenti az mCRPC kezelésében.

\section{Hösokkfehérje (HSP)}

A cochaperonok csoportjába tartozó HSP-k elengedhetetlen szerepet töltenek be az AR-ek stabilitásában, ligandkölcsönhatásában, nukleáris transzlokációjában, DNS-hez való kötődésében. A HSP-funkció gátlásával instabil, funkciót vesztett AR jön létre, emiatt a HSP-k gátlása mCRPC-ben alternatív terápiás célpont lehet.

Két különböző HSP90-gátló anyag, a 17-AAG és az IPI-504 fázis II-es vizsgálatok során klinikai alkalmazásra alkalmatlannak bizonyultak $[33,34]$. Az onalespibet és ganetespibet tesztelö fázis II-es vizsgálatok eredményeit még egyelőre nem közölték.

\section{Transzkripciógátlás}

\section{Kofaktorgátlás}

Egy másik posztreceptorkezelési stratégia azon kofaktorok megcélzását jelentené, amelyek jelentős szerepet töltenek be az AR-ek transzkripciójában. Ígéretesnek tűnt az AT-101, amely képes gátolni az SRC-1-et és -3-at és elősegíteni a prosztata-daganatsejtek apoptózisát is. Az AT-101 minimális antitumor-aktivitást mutatott az mCRPC-ben szenvedő betegek körében végzett fázis I/ II-es klinikai kísérletek során, de fázis II-es vizsgálatban docetaxellal kombinálva nem mutatott további aktivitást [35]. Egyelőre nem ismeretes olyan kofaktorra ható szer, amely fázis II-es vizsgálaton továbbjutott.

\section{N-terminális transzaktivációs domén gátlása}

Ahogy azt korábban is láthattuk, a kutatások egy része továbbra is receptoriális szinten az LBD-re fókuszál, miközben az AR motorjának a transzkripcióért felelős N-terminális domént tekintik. Splice-variánsok kialakulásánál ez a domén folyamatosan aktív marad, ligand bekötődése nélkül is. Ennek a szakasznak a gátlása nagy jelentőséggel bírhat.

Egy lehetséges hatóanyag az EPI-001, amely közvetlenül támadja az AR-eket azáltal, hogy leköti az AF-1 domént és gátolja a transzaktivációját [36]. Ez a mechanizmus előrevetíti annak lehetőségét, hogy a rezisztencia hátterében álló ligandfüggetlen AR-splice-variánsok esetében is hatékony gyógyszer állhasson a klinikus rendelkezésére.

\section{Következtetés}

Metasztatikus, kasztrációrezisztens prosztatadaganatban az androgénreceptor mediálta folyamatok pontosabb megismerése vezetett a ma már klinikai gyakorlatban is rutinszerúen alkalmazott abirateron és enzalutamid fejlesztéséhez. Az újabb előrelépést a fenti szerek ellen kialakuló rezisztencia megértése és az erre irányuló kezelési stratégiák jelenthetik.

A jövőben sürgető szükség van olyan validált prediktív biomarkerek meghatározására, amelyek lehetővé teszik mCRPC-ben szenvedő betegeinknél is a személyre szabott terápiát.

Anyagi támogatás: A közlemény megírása anyagi támogatásban nem részesült.

Szerzôi munkamegosztás: A szerzők egy-egy fejezet megírásával járultak hozzá az összefoglaló kézirat elkészítéséhez, felsorolásuk sorrendjével csökkenő jelentőségben. A cikk végleges változatát valamennyi szerző elolvasta és jóváhagyta.

Érdekeltségek: A szerzőknek nincsenek érdekeltségeik.

\section{Irodalom}

[1] Huggins, C., Hodges, C.: Studies on prostatic cancer. I. The effect of castration, of estrogen and of androgen injection on serum phosphatases in metastatic carcinoma of the prostate. Cancer Res., 1941, 1, 293-297.

[2] Sweeney, C., Chen, Y. H., Carducci, M., et al.: Impact on overall survival (OS) with chemohormonal therapy versus hormonal therapy for hormone-sensitive newly metastatic prostate cancer (mPrCa): An ECOG-led phase III randomized trial. 2014 ASCO Annual Meeting. J. Clin. Oncol., 2014, 32 (5 Suppl.), Abstract LBA2.

[3] Sweeney, C. J., Chen, Y. H., Carducci, M., et al.: Chemohormonal therapy in metastatic hormone-sensitive prostate cancer. N. Engl. J. Med., 2015, 373, 737-746.

[4] Longo, D. L.: New therapies for castration-resistant prostate cancer. N. Engl. J. Med., 2010, 363(5), 479-481.

[5] EAU Guidelines on Prostate Cancer. www.uroweb.org

[6] Friedlander, T. W., Ryan, C. J.: Targeting the androgen receptor. Urol. Clin. North Am., 2012, 39(4), 453-464.

[7] Sadar, M. D.: Small molecule inhibitors targeting the "achilles' heel" of androgen receptor activity. Cancer Res., 2011, 7l(4), 1208-1213.

[8] Zoubeidi, A., Zardan, A., Beraldi, E., et al.: Cooperative interactions between androgen receptor (AR) and heat-shock protein 27 facilitate AR transcriptional activity. Cancer Res., 2007, 67(21), 10455-10465.

[9] Knudsen, K. E., Kelly, W. K.: Outsmarting androgen receptor: creative approaches for targeting aberrant androgen signaling in advanced prostate cancer. Expert Rev. Endocrinol. Metab., $2011,6(3), 483-493$.

[10] Küronya, Z., Bíró, K., Géczy, L., et al.: Treatment strategies for advanced prostate cancer. [Kezelési stratégiák előrehaladott prosztatadaganatban.] Magy. Onkol., 2015, 59(3), 229-240. [Hungarian]

[11] Oh, W. K.: The evolving role of estrogen therapy in prostate cancer. Clin. Prostate Cancer, 2002, 1(2), 81-89. 
[12] Seidenfeld, J., Samson, D. J., Hasselblad, V., et al.: Single-therapy androgen suppression in men with advanced prostate cancer: a systematic review and meta-analysis. Ann. Intern. Med., 2000, 132(7), 566-577.

[13] Klotz, L., Boccon-Gibod, L., Shore, N. D., et al.: The efficacy and safety of degarelix: a 12-month, comparative, randomized, openlabel, parallel-group phase III study in patients with prostate cancer. BJU Int., 2008, 102(11), 1531-1538.

[14] Taylor, C. D., Elson, P., Trump, D. L.: Importance of continued testicular suppression in hormone-refractory prostate cancer. J. Clin. Oncol., 1993, 11(11), 2167-2172.

[15] Yin, L., Hu, Q.: CYP17 inhibitors - abiraterone, C17,20-lyase inhibitors and multi-targeting agents. Nat. Rev. Urol., 2014, $11(1), 32-42$

[16] Trump, D. L., Havlin, K. H., Messing, E. M., et al.: High-dose ketoconazole in advanced hormone-refractory prostate cancer: endocrinologic and clinical effects. J. Clin. Oncol., 1989, 7(8), 1093-1098.

[17] De Bono, J. S., Logothetis, C. J., Molina, A., et al.: Abiraterone and increased survival in metastatic prostate cancer. N. Engl. J. Med., 2011, 364(21), 1995-2005.

[18] Ryan, C. J., Smith, M. R., de Bono, J. S., et al.: Abiraterone in metastatic prostate cancer without previous chemotherapy. $\mathrm{N}$. Engl. J. Med., 2013, 368(2), 138-148.

[19] Kaku, T., Hitaka, T., Ojida, A., et al.: Discovery of orteronel (TAK-700), a naphthylmethylimidazole derivative, as a highly selective 17,20-lyase inhibitor with potential utility in the treatment of prostate cancer. Bioorg. Med. Chem., 2011, 19(21), 6383-6399.

[20] Fizazi, K., Jones, R., Oudard, S., et al.: Phase III, randomized, double-blind, multicenter trial comparing orteronel (TAK-700) plus prednisone with placebo plus prednisone in patients with metastatic castration-resistant prostate cancer that has progressed during or after docetaxel-based therapy: ELM-PC 5. J. Clin. Oncol., 2015, 33(7), 723-731.

[21] Prostate Cancer Trialists' Collaborative Group: Maximum androgen blockade in advanced prostate cancer: an overview of the randomised trials. Lancet, 2000, 355(9214), 1491-1498.

[22] Gillessen, S., Omlin, A., Attard, G., et al.: Management of patients with advanced prostate cancer: recommendations of the St. Gallen Advanced Prostate Cancer Consensus Conference (APCCC) 2015. Ann. Oncol., 2015, 26(4), 1589-1604.

[23] Scher, H. I., Fizazi, K., Saad, F., et al.: Increased survival with enzalutamide in prostate cancer after chemotherapy. N. Engl. J. Med., 2012, 367(13), 1187-1197.

[24] Loriot, Y., Miller, K., Sternberg, C. N., et al.: Effect of enzalutamide on health-related quality of life, pain, and skeletal-related events in asymptomatic and minimally symptomatic, chemotherapy-naive patients with metastatic castration-resistant prostate cancer (PREVAIL): results from a randomised, phase 3 trial. Lancet Oncol., 2015, 16(5), 509-521.
[25] Rathkopf, D. E., Morris, M. J., Fox, J. J., et al.: Phase I study of ARN-509, a novel antiandrogen, in the treatment of castrationresistant prostate cancer. J. Clin. Oncol., 2013, 31(28), 35253530.

[26] Moilanen, A. M., Riikonen, R., Oksala, R., et al.: Discovery of ODM-201, a new-generation androgen receptor inhibitor targeting resistance mechanisms to androgen signaling-directed prostate cancer therapies. Sci. Rep., 2015, 5, 12007.

[27] Zhang, H., Zhan, ., Liu, X., et al.: Splicing variants of androgen receptor in prostate cancer. Am. J. Clin. Exp. Urol., 2013, l(1), $18-24$.

[28] Antonarakis, E. S., Lu, C., Wang, H., et al.: AR-V7 and resistance to enzalutamide and abiraterone in prostate cancer. N. Engl. J. Med., 2014, 371(11), 1028-1038.

[29] Antonarakis, E. S.: Predicting treatment response in castrationresistant prostate cancer: could androgen receptor variant- 7 hold the key? Expert Rev. Anticancer Ther., 2015, 15 (2), 143-145.

[30] Njar, V. C., Brodie, A. M.: Discovery and development of Galeterone (TOK-001 or VN/124-1) for the treatment of all stages of prostate cancer. J. Med. Chem., 2015, 58(5), 2077-2087.

[31] Liu, C., Lou, W., Zhu, Y., et al.: Niclosamide inhibits androgen receptor variants expression and overcomes enzalutamide resistance in castration-resistant prostate cancer. Clin. Cancer Res., 2014, 20(12), 3198-3210.

[32] Wadosky, K. M., Koochekpour, S.: Therapeutic rationales, progresses, failures, and future directions for advanced prostate cancer. Int. J. Biol. Sci., 2016, 12(4), 409-426.

[33] Heath, E. I., Hillman, D. W., Vaishampayan, U., et al.: A phase II trial of 17-allylamino-17-demethoxygeldanamycin in patients with hormone-refractory metastatic prostate cancer. Clin. Cancer Res., 2008, 14(23), 7940-7946.

[34] Oh, W. K., Galsky, M. D., Stadler, W. M., et al.: Multicenter phase II trial of the heat shock protein 90 inhibitor, retaspimycin hydrochloride (IPI-504), in patients with castration-resistant prostate cancer. Urology, 2011, 78(3), 626-630.

[35] Sonpavde, G., Matveev, V., Burke, J. M., et al.: Randomized phase II trial of docetaxel plus prednisone in combination with placebo or AT-101, an oral small molecule Bcl-2 family antagonist, as first-line therapy for metastatic castration-resistant prostate cancer. Ann. Oncol., 2012, 23(7), 1803-1808.

[36] Myung, J. K., Banuelos, C. A., Fernandez, J. G., et al.: An androgen receptor $\mathrm{N}$-terminal domain antagonist for treating prostate cancer. J. Clin. Investigation, 2013, 123(7), 2948-2960.

(Küronya Zsófia dr., Budapest, Ráth György u. 7-9., 1122 e-mail: kuronyaz@gmail.com) 